\title{
Physics Textbook Enriched Augmented Reality: Easy Way to Understand The Physical Concept
}

\author{
Dewi Muliyati ${ }^{1}$, Diniar Hikayah Baiti ${ }^{2}$, Fauzi Bakri $^{3}$, Handjoko Permana ${ }^{4}$ \\ \{dmuliyati@unj.ac.id ${ }^{1}$, dinidiniar21@gmail.com², fauzi-bakri@unj.ac.id $\left.{ }^{3}\right\}$ \\ Physics Education Department, Universitas Negeri Jakarta ${ }^{1,2,3,4}$
}

\begin{abstract}
Physics textbooks presented in multiple representations in the form of images, tables, graphs, exposures, sample problems still cause misconceptions. The addition of 3D animations and videos through augmented reality technology in textbooks is expected to reduce misconceptions in understanding physics concepts. This research was conducted by the research and development method of the Dick and Carey model. The instrument used was a Likert scale questionnaire. The assessment of the feasibility of the book by material experts, media experts, physics teachers gives a very decent interpretation. Trials limited to students who use books independently give a normalized gain value of 0.35 . It was concluded that the physics textbook enriched with augmented reality technology was worthy of being used as a learning resource in learning physics in high school.
\end{abstract}

Keywords: Textbook, Multiple Representations, Augmented Reality, Learning Physics

\section{Introduction}

In understanding subject matter students are assisted with appropriate learning media. Learning media can improve the learning process of students in learning that can affect the achievement of learning outcomes [1]. Science teachers always use books to support learning [2], [3]. Classroom learning requires $75 \%$ of textbooks and homework needs to be supported with $90 \%$ of textbooks [4]. Textbooks are one of the causes of misconceptions for students [5]. There are five causes of misconceptions among students, namely the students themselves, the teacher, the textbook, the learning media, and the teacher's teaching method [6]. The material presented in multiple representations such as concept maps, pictures, videos, tables of experimental results, graphs of data tables, verbal exposures, mathematical equations, example problems, and application forms, can improve understanding and reduce students' misconceptions about physics concepts [7]

One technology that can enrich representation in books is augmented reality (AR) technology. With AR technology, book media can be enriched with video and 3D animation media. Augmented reality is defined as the expansion of physical reality by adding layers of information generated by the computer to the actual environment [8]. Augmented reality is more than just a simple viewer technology, but also a new type of real-time natural user interface for human interaction with objects and digital devices [9]. Augmented reality can improve the efficiency of the educational process [10] [11] Augmented reality allows each student to have a unique discovery pathway through the symbiosis of real-life between technology and learning $[12,13]$. 
Based on this, this research focuses on the development of physics textbook models enriched with 3D media through augmented reality technology. This book can display multiple concepts of physics representation of science-supported by 3D media from augmented reality technology.

\section{Method}

The operational objective of this research is to produce physics textbooks enriched with 3D media with Augmented Reality technology that is feasible to be used by odd semester X HighSchool students. This research was conducted at the Physics Education Digital Media Laboratory, Physics Education Study Program, Faculty of Mathematics and Natural Sciences, Jakarta State University. The research instrument consisted of a Likert scale questionnaire to test the feasibility of the material and media of textbooks, as well as a test instrument to measure students' knowledge improvement after using physics textbooks enriched with 3D media with Augmented Reality technology. The product trial was conducted at SMA Negeri 6 Bekasi and SMA Negeri 1 Bekasi. The research was conducted by the research and development method of Dick and Carey's model. This research was conducted from November 2017 to August 2019.

\section{Result and Discussion}

The product of this research is a physics textbook enriched by Augmented Reality technology. The use of Augmented Reality is assisted by smartphone devices with the Android operating system, with marker detection using the camera on the device in real-time. Then other content will appear in the form of 3D animation or video on the device's screen. The development of textbooks begins with the preparation of textbook material. Next, determine the illustrations that will be used and create 3D animations and videos. Next, create an APK extension to be installed on a smartphone.

The next stage is formative evaluation in the form of validation tests and user trials. The results of validation by material experts get an average percentage of $91,17 \%$ as shown on Table 1 , with a very worthy interpretation for each subject matter.

Table 1. The results of validation by material experts.

\begin{tabular}{lc}
\hline \multicolumn{1}{c}{ Subject } & Scores (\%) \\
\hline Nature of physics and measurement & $89,03 \%$ \\
Vectors & $94,19 \%$ \\
Linear motion kinematics & $93,54 \%$ \\
two-dimensional motion (parabolic motion) & $90,32 \%$ \\
Circular motion & $88,76 \%$ \\
$\quad$ Average & $91,17 \%$ \\
\hline
\end{tabular}

Next is the validation test by media experts who gets an average percentage of $91,17 \%$ with a very worthy interpretation (Table 2). 
Table 2. The results of validation by media experts.

\begin{tabular}{lc}
\hline \multicolumn{1}{c}{ Components } & Score (\%) \\
\hline Textbook Components & $84 \%$ \\
Size of Textbooks & $100 \%$ \\
Book Leather Pages Design & $87,5 \%$ \\
Book Content Layout & $95,7 \%$ \\
Book Content Typography & $90 \%$ \\
Illustration of Book Content & $80 \%$ \\
Augmented Reality Media & $80 \%$ \\
Average & $88,51 \%$ \\
\hline
\end{tabular}

Next is the trial product for use by physics teachers and students. Product trials by the teacher showed a percentage of achievements of $92.86 \%$ with a very worthy interpretation as can be seen on Table 3 .

Table 3. Test Results by Teachers.

\begin{tabular}{lc}
\hline \multicolumn{1}{c}{ Indicator } & Score (\%) \\
\hline Materials suitability & $92,36 \%$ \\
Material Presentation Techniques & $99,01 \%$ \\
Writing Grammar & $91,6 \%$ \\
Augmented Reality Media & $94,3 \%$ \\
Average & $92,86 \%$ \\
\hline
\end{tabular}

While the results of product trials by students show a percentage of achievements of $90 \%$ so that the interpretation of the assessment is very worthy as shown on Table 4.

Table 4. Test Results by Students.

\begin{tabular}{lc}
\hline \multicolumn{1}{c}{ Indicator } & Score (\%) \\
\hline Textbook display & $89 \%$ \\
Presentation of material in textbooks & $89,89 \%$ \\
Augmented Reality Media & $90 \%$ \\
Average & $90 \%$ \\
\hline
\end{tabular}

Furthermore, pre-test and post-test were conducted to see the effect of the use of physics textbooks enriched by Augmented Reality on students' cognitive knowledge. The result of pretest and post-test by students obtained an average pre-test value of 25,12 and a post-test value of 50,49 so that the $\mathrm{N}$-gain obtained was 0,35 with moderate interpretation as can be seen on Table 5. Figure 1 and Figure 2 below is a display of the book and the Augmented Reality application that has been developed 
Table 5. The result of Pre-test and Post-test.

\begin{tabular}{lccc}
\hline \multicolumn{1}{c}{ Subject } & \multicolumn{2}{c}{ Score } \\
& Pre-test & Post-test & N-Gain \\
\hline Nature of physics and measurement & 40 & 66,25 & 0,437 \\
Vectors & 25 & 48,1 & 0,308 \\
Linear motion kinematics & 13,1 & 40,62 & 0,316 \\
two-dimensional motion (parabolic motion) & 28,1 & 50 & 0,304 \\
Circular motion & 19,4 & 47,5 & 0,4 \\
Average & 25.12 & 50.49 & 0.35 \\
\hline
\end{tabular}

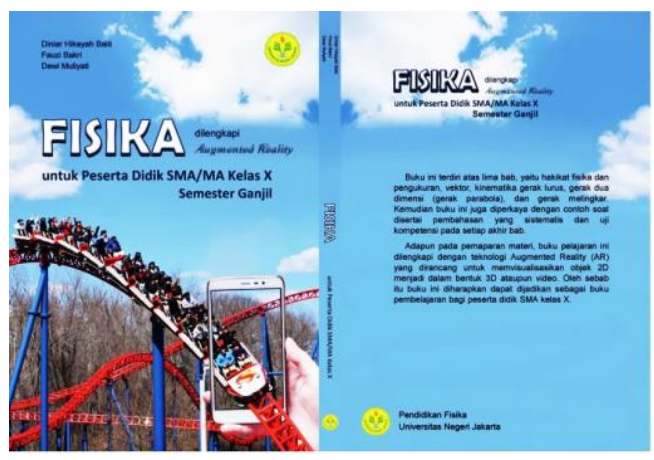

(a)

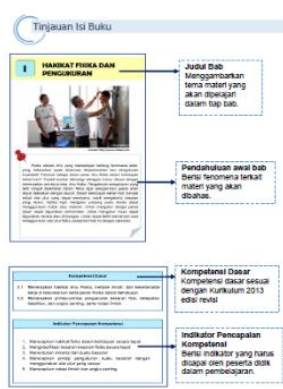

(b)

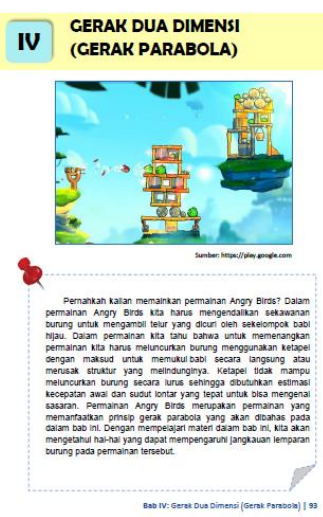

(c)

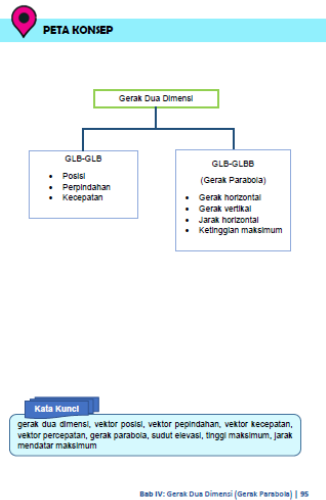

(d)

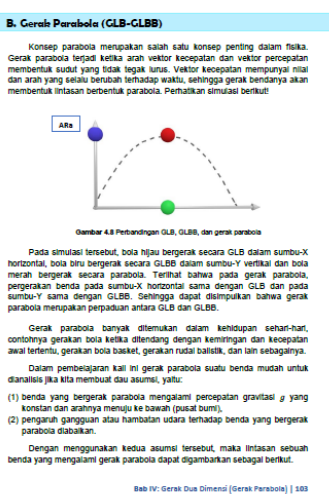

(e) 


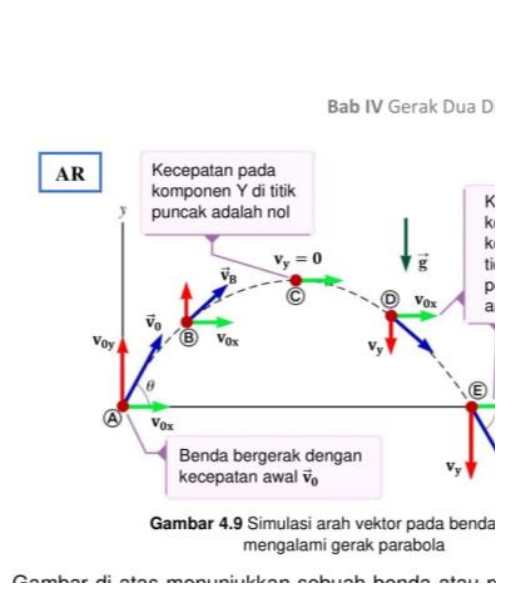

(f)

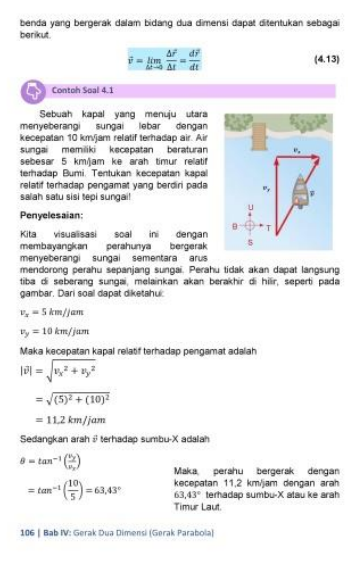

(g)

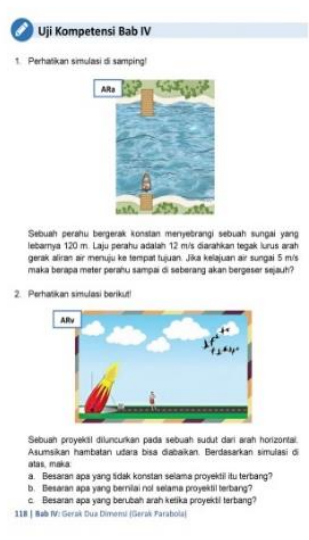

(h)

Fig 1. Example of an AR enriched book display; (a) book cover; (b) review of the contents of the book; (c) the initial introduction to the chapter; (d) concept maps; (e) description of material; (f) AR markers on the marker image; (g) example problems; (h) competency test at the end of the chapter.

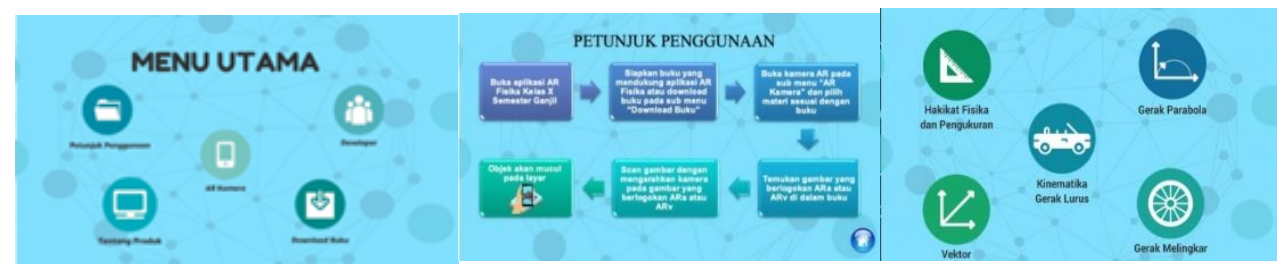

(a)

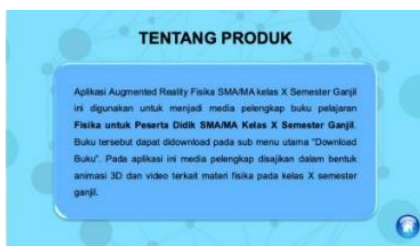

(d)

(b)

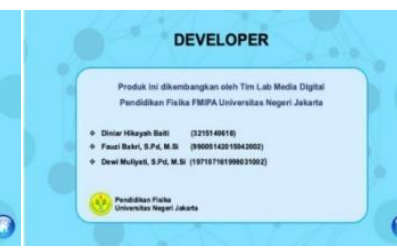

(e)

(c)

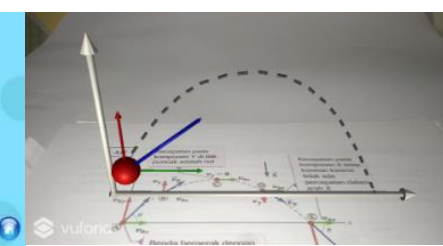

(f)

Fig. 2. Display Augmented Reality application; (a) main menu; (b) instructions for use; (c) cameras for each chapter of material; (d) about the product; (e) developer; (f) AR maker when scanned. 


\section{Conclusion}

Has produced high school physics textbooks that are displayed in multiple representations of science. The book presents material in a variety of representations, starting with video or animation as a stimulus, presentation of material begins with phenomena, assessment of concepts from observations, data tables and graphs, formulation of mathematical equations, study of material, examples of questions and practice questions and application videos that are displayed with augmented reality technology.

Based on the results of a formative evaluation of physics textbooks enriched with 3D media through augmented reality technology, it is appropriate to be used as a source of learning for high school class $\mathrm{X}$ students in an odd semester.

\section{References}

[1] Sudjana, N., \& Rivai, A.: Media Pengajaran. Bandung: Sinar Baru (2001)

[2] Kirk, M. M.: The Trouble with Textbooks. The Science Teacher, 68 (9), pp. $42-45$ (2001)

[3] Adisendjaja, Y. H.: Analisis buku ajar sains berdasarkan literasi ilmiah sebagai dasar untuk memilih buku ajar sains (biologi). Diseminarkan dalam Seminar Nasional Pendidikan Biologi dan Biologi di Jurusan Pendidikan Biologi FPMIPA UPI, pp. 1-8 (2007)

[4] Blystone, R. V., \& Rosen, W. G.: High-School Biology Today and Tomorrow: Papers Presented at a Conference. Washington, D. C. National Academy of Sciences (1989)

[5] Çobanoğlu, E. O.: Underlining the Problems in Biology Textbook for 10th Grades in High School Education Using the Suggestions of Practicing Teachers. Turkish Science Education, Volume 6, Issue 2, pp.75-91 (2009)

[6] Suparno, P.: Miskonsepsi \& Perubahan Konsep dalam Pendidikan Fisika. Jakarta: Gramedia Widiasarana (2013)

[7] Bakri, F, and Muliyati, D, Design of multiple representations e-learning resources based on a contextual approach for the basic physics cours, Journal of Physics: Conf. Series 1013 (2018) 012037 doi :10.1088/1742-6596/1013/1/012037

[8] Julie C.: Augmented Reality: An Overview. In: Carmigniami; Furth (eds.): Handbook of Augmented Reality," Springer, New York. pp. 3-46 (2011)

[9] Glockner, H.: Augmented Reality In Logistics. Troisdorf, Germany: DHL Customer Solutions \& Innovation (2014)

[10] Putri, W. M.: Pengembangan Media Pembelajaran Berbasis Multimedia Augmented Reality pada Pokok Bahasan Alat Optik. Prosiding Seminar Nasional Fisika (E-Journal). pp. 83-88 (2016)

[11] Lee, K.: Augmented Reality in Education and Training. TeachTrends. Volume 56, Issue 2, pp. 13$21(2012)$

[12] Zhang, Y X.: Interactive Augmented Reality to Support Education. In: Lee N. (eds) Encyclopedia of Computer Graphics and Games. Springer, Cham, pp. 1-8 (2017)

[13] Ko, C H.: The Application of Augmented Reality to Design Education. (Eds.): Edutainment 2011, LNCS 6872, Springer-Verlag Berlin Heidelberg. pp. 20-24 (2011) 